University of Wollongong

Research Online

Faculty of Engineering and Information

Faculty of Engineering and Information

Sciences - Papers: Part B

Sciences

2019

Effect of austenisation temperature on bainite transformation below martensite starting temperature

Junyu Tian

Wuhan University of Science and Technology

Guang Xu

Wuhan University of Science and Technology

Zhengyi Jiang

University of Wollongong, jiang@uow.edu.au

Qing Yuan

Wuhan University of Science and Technology

Guanghui Chen

Wuhan University of Science and Technology

See next page for additional authors

Follow this and additional works at: https://ro.uow.edu.au/eispapers1

Part of the Engineering Commons, and the Science and Technology Studies Commons

Research Online is the open access institutional repository for the University of Wollongong. For further information contact the UOW Library: research-pubs@uow.edu.au 


\title{
Effect of austenisation temperature on bainite transformation below martensite starting temperature
}

\author{
Abstract \\ Effects of austenisation temperature on martensite and bainite transformation behaviour, microstructure, \\ and mechanical properties of a bainitic steel austempered below martensite starting temperature were \\ investigated in this study. Results show that the amount of athermal martensite gradually increased with \\ the increase of austenisation temperature, whereas the amounts of bainite and retained austenite initially \\ increased and then decreased, resulting in the trend of the first increase and then decrease in the product \\ of tensile strength and elongation. In addition, the transformation rate of isothermal bainite after athermal \\ martensite formation revealed a trend of deceleration and then acceleration with austenisation \\ temperature at the beginning period. Moreover, the size of bainite plates decreased first and then \\ increased with austenisation temperature.

\section{Disciplines} \\ Engineering | Science and Technology Studies

\section{Publication Details} \\ Tian, J., Xu, G., Jiang, Z., Yuan, Q., Chen, G. \& Hu, H. (2019). Effect of austenisation temperature on bainite \\ transformation below martensite starting temperature. Materials Science and Technology, 35 (13), \\ 1539-1550.
}

\section{Authors}

Junyu Tian, Guang Xu, Zhengyi Jiang, Qing Yuan, Guanghui Chen, and Haijiang Hu 


\section{Effect of austenization temperature on transformation of bainitic steel} austempered below $\mathrm{Ms}_{\mathrm{s}}$

\section{J.Y. Tian', G. Xu' ${ }^{1, *}$, Z.Y. Jiang ${ }^{2}$, Q. Yuan ${ }^{1}$, G.H. Chen ${ }^{1}$, H.J. Hu${ }^{1}$}

${ }^{1}$ The State Key Laboratory of Refractories and Metallurgy, Wuhan University of Science and Technology, Wuhan 430081, China

${ }^{2}$ School of Mechanical, Materials, Mechatronic and Biomedical Engineering, University of Wollongong, NSW 2522, Australia

* Corresponding author (Guang Xu)

Email: xuguang@wust.edu.cn

\section{$\underline{\text { Abstract }}$}

Effects of prior austenite grain size (PAGS) on martensite and bainite transformation behavior, microstructure, and mechanical properties of a bainitic steel austempered below martensite starting temperature $\left(\mathrm{M}_{\mathrm{s}}\right)$ were investigated in this study. Results show that the amount of athermal martensite (AM) gradually increased with the increase of PAGS, whereas the amounts of bainite and retained austenite (RA) initially increased and then decreased, resulting in the trend of the first increase and then decrease in the product of tensile strength and elongation (PSE). In addition, the transformation rate of isothermal bainite after AM formation revealed a trend of deceleration and then acceleration with PAGS at the beginning period. Moreover, the size of bainite plates decreased first and then increased with PAGS.

Keywords: Prior austenite grain size; Martensite starting temperature; Transformation kinetics; Microstructure; Mechanical properties 


\section{Introduction}

Martensite and bainite transformations play very important roles in improving mechanical properties of steels [1-3]. In some advanced high-strength steels (AHSSs), such as the quenching and partitioning (Q\&P) steels, bainitic steels, and transformationinduced plasticity (TRIP) steels, their superior mechanical properties are directly related to martensite and/or bainite transformations [4-7]. It is well known that the kinetics of bainite and martensite transformations is generally affected by prior austenite grain size (PAGS). Therefore, during the heat treatment of high-strength steels, it is crucial to studying the effects of PAGS on martensite and bainite transformations for achieving better mechanical properties of the steel.

In recent years, innumerable studies have been conducted to investigate the effect of PAGS on martensite transformation [8-10]. For example, Sun et al. [8] investigated the effect of PAGS on martensite transformation and mechanical properties of two highcarbon steels and reported that grain refinement can induce a phase transformation of high carbon martensite substructure from twin to dislocations. Similarly, Prawoto et al. [9] studied the effect of PAGS on the morphology of the martensite microstructure in a medium carbon steel . The block and packet sizes in the martensite increase with the increase of PAGS. It is also well accepted that smaller PAGS causes a significant decrease in martensite starting transformation temperature $\left(\mathrm{Ms}_{\mathrm{s}}\right)$. Hanamura et al. [11] investigated the effect of PAGS on martensite transformation in an air-cooled 0.1C$5 \mathrm{Mn}$ martensitic steel and claimed that the value of $\mathrm{M}_{\mathrm{s}}$ was decreased by $40{ }^{\circ} \mathrm{C}$ with a decrease of PAGS from $254 \mu \mathrm{m}$ to $30 \mu \mathrm{m}$, and similar findings were also reported by 
1 Yang et al. [12] and Garcia-Junceda et al. [13]. In addition, Lee et al. [14] proposed a

2 new $\mathrm{M}_{\mathrm{s}}$ equation and a new martensite transformation kinetics model based on the

3 effect of PAGS, and expounded that the value of $\mathrm{M}_{\mathrm{S}}$ decreased gradually with the

4 decrease of PAGS. The decrease of Ms with smaller PAGS can be explained by the

5 theory of Hall-Petch strengthening effect. Smaller PAGS increases resistance to the

6 invariant-strain deformation of martensite transformation [15].

7 Furthermore, apart from martensite transformation, the effect of PAGS on bainite

8 transformation has also been widely explored [16-20]. Hu et al. [17] investigated the

9 effect of PAGS on isothermal bainitic transformation kinetics in a high-carbon bainitic

10 steel. They elucidated that a coarse PAGS accelerated the transformation of bainite and

11 increased the amount of bainite transformation. Similarly, Xu et al. [18] reported that

12 in a medium carbon bainitic steel, larger PAGS resulted in a higher bainitic

13 transformation rate and increased the volume fraction of transformed bainite.

14 Matsuzaki et al. [19] studied the effects of PAGS on bainite transformation kinetics in

15 a low-carbon bainitic steel and advocated that the increase of PAGS led to an

16 acceleration in transformation kinetics and caused a considerable increase of the

17 amount of transformed bainite. The aforesaid studies emphasize that although larger

18 PAGS yields fewer nucleation sites, and it is beneficial for the growth of bainite sheaves.

19 However, it is important to note that previous studies mainly focused on the effects

20 of PAGS on the single-phase transformation of martensite or bainite; hence, the

21 influences of PAGS on both bainite and martensite transformations during

22 austempering below $\mathrm{M}_{\mathrm{s}}$ have been rarely reported. In recent years, the isothermal 
transformation process austempered below $\mathrm{M}_{\mathrm{s}}$ has been explored to obtain finer bainite microstructures and faster bainitic transformation kinetics [20-22]. The formation of athermal martensite (AM) before the holding process yields more nucleation sites for isothermal bainitic transformation during the isothermal process, thus resulting in finer bainite microstructures and faster bainitic transformation kinetics. In addition, lower austempering temperature causes a larger driving force. It is beneficial for attaining finer bainite microstructures and thus achieves the excellent performance [23]. Therefore, it is necessary to investigate the effects of PAGS on martensitic and bainitic transformations in bainitic steels austempered below Ms. Moreover, according to the results of above references [11-14], it is found that a reduction in PAGS lowers $\mathrm{Ms}_{\mathrm{s}}$ and also decreases the amount of AM before isothermal holding due to smaller undercooling [11-14]. Consequently, more residual austenite films and blocky particles are formed for bainite transformation, thus resulting in an increase of the amount of transformed bainite. However, at the same time, the reduction of PAGS also leads to a decrease of the amount of bainite itself [17-19]. Hence, two opposite effects occur on transformed bainite due to different PAGSs when the austempering temperature is below Ms. The effect of PAGS on bainite transformation during austempering below $\mathrm{M}_{\mathrm{s}}$ has not been clearly identified. Therefore, it is indispensable to investigate the effects of different PAGS on martensite and bainite transformation behavior, microstructures, and mechanical properties of a low-carbon bainite steels austempered below $\mathrm{M}_{\mathrm{s}}$, and the obtained results could provide useful information to understand how PAGS affects both martensitic and isothermal bainitic transformations during austempering below Ms. 


\section{Materials and experimental procedure}

\subsection{Materials}

The experimental steel (chemical composition Fe-0.221C-1.802Si-2.013Mn 0.227Mo-0.984Cr (wt\%)) was first refined in a $50 \mathrm{~kg}$ laboratory-scale vacuum furnace, then hot-rolled to $12 \mathrm{~mm}$ thick plates on a four-high mill, and finally, air-cooled to room temperature. A considerable Si content was added to the steel in order to effectively prevent the formation of brittle carbides [24]. Further, the addition of manganese (Mn) and chromium (Cr) increased the stability and the hardenability of undercooled austenite, and consequently, enlarged the range of bainitic transformation $[25,26]$. Moreover, molybdenum (Mo) was added to expedite the bainitic transformation and prevent temper embrittlement [27].

\subsection{Methods}

Thermal simulation experiments were conducted on a Gleeble-3500 simulator. Cylindrical samples of $6 \mathrm{~mm}$ diameter and $100 \mathrm{~mm}$ length were prepared. Dilatations of the samples along the radial direction were measured during the entire experimental process. The $A c_{3}$ temperatures of the tested steels were calculated as $831{ }^{\circ} \mathrm{C}$ according to the Andrews formula [28] (Eq. (1)). For obtaining the full austenized microstructure, the range of austenitizing temperature of $1000-1250{ }^{\circ} \mathrm{C}$ was selected to obtain different PAGS.

$$
\begin{gathered}
A c_{3}\left({ }^{\circ} \mathrm{C}\right)=910-203 \sqrt{x_{C}}-15.2 x_{N i}+44.7 x_{S i}+104 x_{V}+31.5 x_{M o}+13.1 \\
x_{W}-30 x_{M n}-11 x_{C r}-20 x_{C u}+700 x_{P}+400 x_{A l}+20 x_{A s}+400 x_{T i}
\end{gathered}
$$

where $x_{i}$ is the mass percentage of the element “ $i$ ”. In addition, the bainite and martensite starting temperatures ( $\mathrm{B}_{\mathrm{s}}$ and $\mathrm{M}_{\mathrm{s}}$ ) of the tested steel were $501^{\circ} \mathrm{C}$ and $352^{\circ} \mathrm{C}$, 
1 respectively, calculated by MUCG83 software developed by Bhadeshia at Cambridge

2 University [29]. In addition, the curves of transformation time temperature (TTT) for

3 the tested steel calculated by MUCG83 software is given in Fig. 1 in the supplemental

4 materials.

5 The samples were heated to different austenitizing temperatures of $1000{ }^{\circ} \mathrm{C}$,

$61100{ }^{\circ} \mathrm{C}, 1200{ }^{\circ} \mathrm{C}$, and $1250{ }^{\circ} \mathrm{C}$ at heating rate $10^{\circ} \mathrm{C} / \mathrm{s}$ and held for $10 \mathrm{~min}$ to obtain different PAGSs. After austenitization, all samples were cooled down to $320{ }^{\circ} \mathrm{C}$, held for $30 \mathrm{~min}$ to form martensite and austenite, and finally, air cooled to room temperature. The proposed heat treatment procedure is presented in detail in Fig. 1.

Fig. 1

\subsection{Characterization}

The heat-treated samples were mechanically polished and etched with a $4 \%$ nital to perform microstructural characterization. A Nova 400 Nano-field emission scanning electron microscope (FE-SEM) coupled with an electron backscatter diffraction (EBSD) measurements was used to observe microstructures and fracture morphologies, and the crystallographic orientation relationship between different phases. In addition, a JEM2100F transmission electron microscope (TEM) was also used to observe the finer microstructure. Tensile tests were carried out on a UTM-4503 electronic universal tensile tester (with a cross-head speed of $1 \mathrm{~mm} / \mathrm{min}$ ) at room temperature, and an average value of three tensile test data was considered for each sample in order to maintain the accuracy. The volume fraction of RA was determined by X-ray diffraction (XRD) experiments on an Empyrean diffractometer (equipped with an unfiltered Co$\mathrm{K} \alpha$ radiation source) operating at $35 \mathrm{kV}$ and $50 \mathrm{~mA}$. The step size and the counting time for XRD were set to $0.0263^{\circ}$ and 77.265 s, respectively.

\section{Results and Discussion}




\subsubsection{Dilatation}

Fig. 2a displays the variations in the programmed and thermocouple temperatures against time for the sample austenitized at $1000{ }^{\circ} \mathrm{C}$ (during the entire heat treatment process). The insert image in Fig. 2a reveals that apart from the temperature overshot from 320.0 to $317.6^{\circ} \mathrm{C}$, the temperature fluctuation was $\pm 1^{\circ} \mathrm{C}$, and it indicates that the thermocouple mainly followed the programmed temperature. The small temperature overshot disappeared in a very short time. Therefore, the effect of temperature fluctuation was found to be negligible.

Fig. 2b exhibits the corresponding dilatation curves against temperature. The slope change at about $550{ }^{\circ} \mathrm{C}$ during heating in Fig. $2 \mathrm{~b}$ may be caused by the dissolution of previous carbides and the tempering of phase products. The values of $A c_{1}$ and $A c_{3}$ temperatures were measured as $792{ }^{\circ} \mathrm{C}$ and $875{ }^{\circ} \mathrm{C}$, respectively, based on the tangent method. Hence, it confirms that the temperature of $1000^{\circ} \mathrm{C}$ was high enough to achieve the full austenitization microstructure. Moreover, during the cooling process from $1000{ }^{\circ} \mathrm{C}$ to $\mathrm{Ms}$ (point A), the dilatation curve was found to be a straight line, thus indicating that no high-temperature products were formed due to the high cooling rate of $20^{\circ} \mathrm{C} / \mathrm{s}$. Fig. 2c shows that how to determine the temperature of $\mathrm{M}_{\mathrm{s}}$, and it indicates that $\mathrm{M}_{\mathrm{S}}$ is $354 \pm 3{ }^{\circ} \mathrm{C}$ for the sample austenized at $1000{ }^{\circ} \mathrm{C}$. According to the result proposed by Bhadeshia et al. [30], the conventional method to determine the $\mathrm{M}_{\mathrm{S}}$ is uncertain, so in the present study, the offset method is used and ensures that the determination of $\mathrm{M}_{\mathrm{s}}$ is more reproducible. The details of Bhadeshia's offset method for determining $\mathrm{M}_{\mathrm{S}}$ is given in the supplemental materials. After point $\mathrm{A}\left(\mathrm{M}_{\mathrm{s}}\right)$, the dilatation curve manifested an obvious increase in the dilatation from points A to B (corresponding to the holding temperature of $320{ }^{\circ} \mathrm{C}$ ). It signifies that some transformation occurred before holding at a high cooling rate of $20^{\circ} \mathrm{C} / \mathrm{s}$. It can be 
1 inferred that the increase of dilatation from points A to B is caused by martensite

2 transformation (similar results have been also reported in our previous study [22]).

3 After isothermal treatment the slope change of the curve is caused by fresh martensite

$4 \quad$ (FM) transformation (Fig. 2b). Furthermore, by the same method, the Ms temperatures

5 of other three samples austenitized at $1100{ }^{\circ} \mathrm{C}, 1200{ }^{\circ} \mathrm{C}$, and $1250{ }^{\circ} \mathrm{C}$ were calculated

6 to be $359 \pm 2.2{ }^{\circ} \mathrm{C}, 370 \pm 3.0^{\circ} \mathrm{C}$, and $376 \pm 1.9^{\circ} \mathrm{C}$ respectively. (The corresponding

7 dilatation curves of other three samples are given in Fig. 2 in the supplemental

8 materials.) Therefore, the value of $\mathrm{M}_{\mathrm{S}}$ increased with the increase of austenitizing

9 temperature, and this result is consistent with the findings reported by Hanamura et al. $10 \quad[11]$

Fig. 3 displays the dilatation curves of the samples austenitized at different temperatures in the range of $1000-1250{ }^{\circ} \mathrm{C}$. Fig. 3a illustrates the curves of total dilatation (from point A (Fig. 2b) to the end of the holding process) as a function of time (the time at point A was selected as the zero point of the abscissa and the ordinate axes). According to the previous study [22], the total dilatation of all samples austempered below Ms can be divided into two parts (based on the inflection points a, b, c, and d): dilatation caused by athermal martensite transformation $\left(\mathrm{D}_{\mathrm{AM}}\right)$ and dilatation caused by bainite transformation $\left(\mathrm{D}_{\mathrm{B}}\right)$. It is observable from Fig. 3a that dilatation increases dramatically before the corresponding inflection point. However,

21 after corresponding inflection point, the increasing trend in dilatation tends to slow down significantly. The rapid increase of dilatation is caused by the formation of athermal martensite (AM), whereas the slow increase of dilatation is due to the isothermal bainitic transformation [22,23,31]. Fig. 3b presents dilatations as a function of holding time during isothermal transformation at $320^{\circ} \mathrm{C}$ (the beginning of isothermal 
1 bainite transformation was selected as the zero point of the abscissa and the ordinate axes). The transformation temperature was constant and no extra force was applied to the sample during isothermal holding, thus the dilatation in Fig. 3b represents the real amount of bainite transformation. On the basis of dilatation results in Figs. 3a and 3b, the variations in $\mathrm{D}_{\mathrm{Am}}$ and $\mathrm{D}_{\mathrm{B}}$ against austenitization temperature are presented in Fig. 3c. It is noticeable that $\mathrm{D}_{\mathrm{Am}}$ increased with the increase of austenitization temperature, whereas $D_{B}$ increased first and then decreased. When the sample was austenitized at $1200{ }^{\circ} \mathrm{C}, \mathrm{D}_{\mathrm{B}}$ reached the maximum value. In addition, according to the result shown in Fig. 3b, the curves of dilatation change rate indicating bainite transformation kinetics are plotted in Fig. 3d. It shows that the initial transformation rate first decreases and then increases with the increase of austenization temperature. It is known that bainite transformation contains nucleation and growth. According to the sub-unit theory proposed by Bhadeshia [29], a sub-unit nucleates at austenite grain boundary and lengthens until its growth is arrested by plastic deformation within the austenite. New sub-units then nucleate at its tip, and the sheaf structure develops as this process continues. Compared to nucleation, the growth of bainite sub-units is much faster. Therefore, the nucleation rate has a crucial role on transformation rate at the initial stage of bainite transformation. In the present study, the formation of AM expedites the bainite transformation by providing the more nucleation sites due to the increase of $\gamma / \alpha$ interface. However, the transformation rate is also affected by the PAGS. The larger PAGS provides less grain boundary area, which is not beneficial to nucleation of bainite transformation. Therefore, when the samples with different PAGS are austempered below $\mathrm{M}_{\mathrm{s}}$, the bainite transformation rate is dependent on the competition between the increase of nucleation sites brought by more AM formation and the decrease by the larger PAGS. In the samples austenized at range of $1000-1200{ }^{\circ} \mathrm{C}$, although the 
1 formation of AM compensates for the partial nucleation sites, the larger PAGS by

2 higher austenized temperature provides less nucleation sites to bainite transformation,

3 leading to the lower transformation rate with the increase of austenization temperature.

4 However, when the sample is austempered at $1250{ }^{\circ} \mathrm{C}$, the role of more nucleation sites

5 brought by more AM formation is larger than that of the decrease of nucleation sites by

6 larger PAGS, so the transformation rate increases. Therefore, at the beginning period,

7 the transformation rate shows a trend of the first deceleration and then acceleration with

8 austenization temperature. The slowest transformation rate occurs in the sample

9 austenized at $1200{ }^{\circ} \mathrm{C}$. However, as transformation progresses, the growth of bainite

10 sheaves is hindered by more austenite grain boundaries. The hindrance of bainite

11 growth less likely happens in larger PAGS, resulting in the different change trend of 12 transformation rate during the subsequent transformation period of 11 400 s. In this 13 period, the largest and slowest transformation rates occur in samples austenized at $141200^{\circ} \mathrm{C}$ and $1250^{\circ} \mathrm{C}$, respectively. Furthermore, the larger interior stress caused by the 15 more AM formation also promotes the bainite transformation. Therefore, the bainite 16 transformation amount increases with the increase of austenization temperature from 171000 to $1200{ }^{\circ} \mathrm{C}$. It is noted that the amount of bainite transformation decreases when 18 the austenization temperature increases from 1200 to $1250{ }^{\circ} \mathrm{C}$. It is mainly attributed to 19 the less residual austenite to be reserved due to the formation of large amount of AM. 20 As a result, the amount of bainite transformation shows the trend of the first increase 21 and then decrease with the increase of austenization temperature.

\subsubsection{Microstructure}

Figs. 4(a-d) display the micrographs of prior austenite grains (PAGs) and prior austenite grain boundaries (PAGBs) of different samples. The values of PAGS were 
1 calculated by Image-Pro Plus software based on the diagonal method. Every nearly complete grain of each micrograph is selected, and two diagonals are drawn randomly in each grain. The average value of the two diagonals is calculated as the size of this grain. Finally, the average value of the size of all grains is selected as the grain size of the whole micrograph. In order to achieve the higher accuracy, at least the results of three micrographs are reported for each sample. The average sizes of PAGSs for different samples austenitized at $1000-1250{ }^{\circ} \mathrm{C}$ were measured as $29.7 \pm 4.3 \mu \mathrm{m}, 38.4$ $\pm 5.7 \mu \mathrm{m}, 52.2 \pm 5.5 \mu \mathrm{m}$ and $61.3 \pm 7.6 \mu \mathrm{m}$, respectively. Therefore, it is observable that larger PAGS values were obtained at higher austenitization temperatures.

Fig. 4

Typical SEM micrographs of the samples treated by different austenitization processes are presented in Fig. 5. The obtained microstructures mainly consisted of bainite, athermal martensite (AM), film-like retained austenite (RA), martensite/austenite islands (M/A), and fresh martensite (FM) [3,22,32]. AM was formed during the cooling process before the holding process, whereas FM was obtained in the final cooling process after the holding process. According to the method provided in Ref. [32], M/A islands, FM, AM and B can be distinguished. Because M/A and FM contained more supersaturated carbon, they were more difficult to be etched than AM, and the strength of AM gradually decreased due to subsequent annealing during the holding process [22], resulting in the convex blocky morphology of M/A and FM and the concave polygonal morphology of AM. Moreover, carbides were also observed in all samples because the tempering of AM during the isothermal holding process led to the precipitation of carbides. The similar results are reported by Toji et 
1 al. [33] and Tariq et al. [34]. In addition, a small amount of FM was observed in the

2 samples austenitized at $1000{ }^{\circ} \mathrm{C}$ (Fig. 5a) and $1250{ }^{\circ} \mathrm{C}$ (Fig. 5d). The phase of FM is

3 not observed in samples austenized at 1100 and $1200{ }^{\circ} \mathrm{C}$ because a large amount of

4 bainite transformation leads to the increase of the stability of untransformed austenite,

5 which is retained at room temperature as M/A and RA.

According to the identification method provided in Ref. [32], B and AM can be distinguished, and then based on the SEM micrographs, the volume fractions of B and AM were calculated using Image-Pro Plus software according to the method depicted in the previous study [22], and the corresponding results are presented in Table 1. It is evident that $V_{\text {Am }}$ increased with the increase of austenitization temperature, whereas $V_{B}$ manifested different changing trends. With the increase of austenitization temperature, $V_{B}$ first increased and then decreased. The maximum value of $V_{B}$ was obtained in the sample austenitized at $1200^{\circ} \mathrm{C}$, whereas the sample austenitized at $1250^{\circ} \mathrm{C}$ yielded the maximum $\mathrm{V}_{\mathrm{AM}}$ and the minimum $\mathrm{V}_{\mathrm{B}}$ values, and these results are consistent with the findings from the dilatation curves in Fig. 3. It is observable from Fig. 4 that the value of PAGS increased from $29.7 \mu \mathrm{m}$ to $61.3 \mu \mathrm{m}$ with the increase of austenitization temperature. The value of $\mathrm{M}_{\mathrm{S}}$ generally increases with the increase of PAGS. Hence, larger undercooling for martensite transformation occurs due to larger PAGS when different samples are austempered at the same temperature [11-14]. It can be explained by the Hall-Petch strengthening effect that smaller PAGS increases resistance to the invariant-strain deformation of martensite transformation [15]. The Hall-Petch 
strengthening effect can be explained by the relationship $\rho \propto 1 / D$, where $\rho$ is dislocation density and D is austenite grain diameter. Therefore, smaller austenite grain diameter results in larger dislocation density. An increase of dislocation density caused by decrease of PAGS will result in a strengthening of the austenitic matrix by the HallPetch effect, increasing the resistance of the austenite to plastic deformation locally as well as macroscopically, which means a bigger impediment to martensite transformation by increasing the non-chemical free energy [12,13]. Therefore, the smaller PAGS leads to the decrease of Ms. In addition, Caballero et al. [35] referred a probability equation (Eq. (2)) applied by Cohen and Olson.

$$
p=1-\exp (-\lambda v)
$$

where $p$ represents the fraction of crystals containing martensite, $v$ is the grain volume, and $\lambda$ is the probability of nucleation of martensite per unit volume which depends on the temperature. The aforesaid equation reveals that the probability of event taking place decreases exponentially as the grain size decreases [35]. Therefore, the amount of AM gradually increased with the increase of PAGS. Regarding to $V_{B}$, it is different from the samples austempered above $\mathrm{M}_{\mathrm{s}}$, and it depends on not only the isothermal temperature and time, but also the amount of AM. The amount of AM increases as PAGS increases, which not only provides more nucleation sites for bainite transformation, but also leads to the less amount of residual austenite for bainitic transformation. That is to say, the AM formation has two opposite effects on the bainite amount. Moreover, PAGS also affects the amount of bainite transformation. With the increase in austenitization temperature from $1000{ }^{\circ} \mathrm{C}$ to $1200{ }^{\circ} \mathrm{C}$, larger PAGS can be 
obtained and generates more bainite phase. It happens because the diffusion coefficient of grain boundary decreases with the increase of PAGS [36]. As a result, the carbon content of residual austenite in coarse PAGS samples hardly reaches to the value predicted by the $T_{0}$ diagram, thus more bainite can be transformed from residual austenite [36]. In the present study, the amount of bainite was closely related to both PAGS and $V_{A M}$. The effect of AM and PAGS and the reason for the change trend of $V_{B}$ are discussed in Section 3.1.1.

Table 1

Fig. 6 depicts the EBSD result of the sample austenitized at $1250{ }^{\circ} \mathrm{C}$. Fig. 6a displays the crystallographic orientation of the sample austenitized at $1250{ }^{\circ} \mathrm{C}$. Fig. 6c presents the corresponding diagram of frequency versus band contrast (in which higher band contrast represents lower stresses in grains). Two peaks can be detected in Fig. 6c, thus indicating the formation of two types of phase products - martensite and bainite. According to the results of Gauss fitting, the boundary value of band contrast for these two peaks was found as 80 (Fig. 6c). The band contrast smaller than 80 is colored by red, and the remaining white area represents the band contrast higher than 80 , thus the red area represents the martensite phase and the white area denotes the bainite phase. It is evident that the red martensite phase in Fig. 6b consisted of AM, FM, and M/As. Moreover, film-like RA was not noticed in the image due to their very small grain size. The volume fraction of white bainite area was calculated as $27.5 \%$ by Image-Pro Plus software (Fig. 6b) [22]. Similarly, the volume fractions of bainite in the samples austenitized at $1000{ }^{\circ} \mathrm{C}, 1100{ }^{\circ} \mathrm{C}$, and $1200{ }^{\circ} \mathrm{C}$ were measured as $31.8 \%$, 36.9\%, and 
$1 \quad 44.1 \%$ respectively. These results are well consistent with the statistical results obtained

2 from SEM microstructures in Fig. 5.

In order to more clearly observe the bainite morphology and measure the sizes of

5 bainite plates, the microstructure corresponding to Fig. 5 is presented in larger magnification in Fig. 7. It is noticeable that carbides only existed in AM, whereas all

7 bainite plates were carbide-free, it can be attributed to the presence of considerable $\mathrm{Si}$

8 content in the experimental bainite steel. Moreover, the thicknesses of bainite plates in

9 different samples were determined by the equation $n=2 L_{t} / \pi$ [5], where $n$ is the thickness of a bainite plate, $L_{t}$ is the mean linear intercept in the direction normal to 11 plate length and was determined by Image-Pro Plus software. The average values of $n$ 12 for the samples austenitized at $1000^{\circ} \mathrm{C}, 1100^{\circ} \mathrm{C}, 1200^{\circ} \mathrm{C}$, and $1250{ }^{\circ} \mathrm{C}$ were measured as $376.5 \pm 15.1 \mathrm{~nm}, 350.8 \pm 21.3 \mathrm{~nm}, 311.4 \pm 19.6 \mathrm{~nm}$, and $352.6 \pm 22.4 \mathrm{~nm}$, respectively. It indicates that the thickness of bainite plates continuously decreased from $1000^{\circ} \mathrm{C}$ to $1200^{\circ} \mathrm{C}$ and then sharply increased from $1200{ }^{\circ} \mathrm{C}$ to $1250^{\circ} \mathrm{C}$. Bainite transformation contains nucleation and growth. According to the sub-unit theory proposed by Bhadeshia [29], a sub-unit nucleates at austenite grain boundary and lengthens until its growth is arrested by plastic deformation within the austenite. Once lengthening stops, thickening of laths can be a way to continue transformation in smaller prior austenite grains. Thickening of laths by sidewise nucleation and growth of new sub-units has been reported in other studies [37]. This thickening can continue as long as the chemical 
1 plates decreases with the increase of PAGS. However, when the austenized temperature

2 increases from 1200 to $1250{ }^{\circ} \mathrm{C}$, the formation of a larger amount $\mathrm{AM}$ leads to the PAG

3 to be divided into several subgrains. The small subgrain limits the lengthening, so it has

4 to transform by the sidewise nucleation and growth. Therefore, the size of bainite plates

5 increases.

Fig. 8 displays the diffraction patterns of the samples austenitized at $1000-1250{ }^{\circ} \mathrm{C}$.

8 The integrated intensities and the angles of diffraction peaks were accurately

9 determined by HighScore Plus software based on the obtained diffraction patterns. The volume fractions of RA ( $\left.V_{\mathrm{RA}}\right)$ of the four samples austenized at different temperatures are calculated according to the integrated intensities of (200) and (211) peaks of ferrite and (200) and (220) peaks of austenite based on Eq. (3).

$$
V_{i}=\frac{1}{1+G\left(I_{\alpha} / I_{\gamma}\right)}
$$

where $V_{\mathrm{i}}$ represents the volume fraction of austenite for each peak; $G$ value is chosen as follows, 2.5 for $I_{\alpha}$ (200)/I $I_{\gamma}$ (200), 1.38 for $I_{\alpha}$ (200)/I $I_{\gamma}$ (220), 1.19 for $I_{\alpha}(211) / I_{\gamma}(200)$, 0.65 for $I_{\alpha}(211) / I_{\gamma}(220) ; I_{\alpha}$ and $I_{\gamma}$ represent the corresponding integrated intensities of ferrite and austenite [38], and the corresponding results are presented in Table 1. It is observed that when the austenitization temperature increased from $1000^{\circ} \mathrm{C}$ to $1100^{\circ} \mathrm{C}$, the amount of RA increased significantly. It is well known that the process of bainite transformation is normally accompanied by the rejection of carbon atoms. When a large number of carbon atoms were ejected in adjacent untransformed austenite due to the formation of bainite, the stability of untransformed austenite was significantly increased. Therefore, the subsequent martensite transformation was retarded by stable 
1

5 a large amount of bainite and AM led to a small amount of untransformed austenite,

untransformed austenite during the cooling process, and consequently, more RA was retained at room temperature. Moreover, the amount of RA generally depends on not only the amounts of bainite, but also the residual austenite after AM formation. With the increase in austenitization temperature from $1100{ }^{\circ} \mathrm{C}$ to $1200{ }^{\circ} \mathrm{C}$, the formation of thus the amount of RA decreased. Similarly, when the austenitization temperature further increased to $1250^{\circ} \mathrm{C}$, a sharp decrease in the amount of RA was observed. It is also attributed to the obvious decrease of bainite transformation amount and the increase of AM amount. It is well known that less amount of bainite transformation means less rejection of carbon atoms into residual austenite, resulting in the unstable residual austenite, which transformed to martensite during final cooling process. Therefore, the amount of RA first increased and then decreased with the rise of austenitization temperature.

Fig. 8

\subsubsection{Tensile test}

Tensile test results of the samples austenitized at different temperatures are presented in Table 2, and the corresponding stress-strain curves are displayed in Fig. 9. It is observable that the values of tensile strength (TS), yield strength (YS), and total elongation (TE) of the samples first increased and then started to decrease. The highest strength and the largest elongation were found in the sample austenitized at $1100{ }^{\circ} \mathrm{C}$, thus resulting in the largest product of tensile strength and elongation (PSE). 
In comparison to the sample austenitized at $1100{ }^{\circ} \mathrm{C}$, the sample austenitized at $100{ }^{\circ} \mathrm{C}$ contained a lower amount of lath-like bainite and RA as well as some hard FM.

Further, the presence of more nano-sized bainite causes higher strength in bainite steels $[5,6,39]$. Moreover, the strength and the elongation of bainitic steels generally depend on the amount of RA produced by the transformation induced plasticity (TRIP) effect. In comparison to the sample austenitized at $1100{ }^{\circ} \mathrm{C}$, less amount of RA was formed in the sample austenitized at $1200{ }^{\circ} \mathrm{C}$, thus resulting in a slight decrease in strength and elongation. In addition, more AM also caused a decrease of strength. It is observable from SEM microstructures in Fig. 7 that carbides were precipitated from AMs. A large amount of AM resulted in more brittle carbides and degraded the mechanical properties of the steel [22]. When the austenitization temperature reached $1250{ }^{\circ} \mathrm{C}$, the strength and the elongation of the steel sharply decreased, it can be attributed to the presence of the smallest amounts of nano-sized bainite and RA and the largest amount of AM (Table 1). Figs. 10a and 10b, respectively, exhibit the TEM microstructure and the tensile fracture morphology of the sample austenitized at $1250{ }^{\circ} \mathrm{C}$. The presence of a large amount of carbides significantly deteriorated the mechanical properties of the steel (Fig. 10a). It is evident from Fig. 10b that the fracture morphology was composed of a large amount of cleavage facet and a small amount of dimple. It is well known that the brittle fracture mode generates cleavage facets, thus resulting in an inferior elongation. On the contrary, ductile fracture forms dimples and yields better elongation [40]. It is noticeable that brittle fracture mainly occurred in the sample austenitized at $1250{ }^{\circ} \mathrm{C}$, 
thus resulting in the worst mechanical properties.

\section{Conclusions}

In the present study, the effects of PAGS on martensitic and bainitic transformation behavior, microstructures, and mechanical properties of a bainitic steel during austempering below $\mathrm{M}_{\mathrm{S}}$ were investigated. The main inferences are depicted below.

(1) With the increase of PAGS, the volume fraction of bainite first increased and then decreased, which is significantly different from the results of samples austempered above $\mathrm{M}_{\mathrm{s}}$. In addition, the volume fraction of AM increased with the increase of PAGS, whereas the volume fraction of RA showed the same change trend with bainite volume fraction.

(2) At the initial stage of transformation, the bainite transformation rate first decelerated and then accelerated with the increase of PAGS, and the sample austenized at $1200{ }^{\circ} \mathrm{C}$ had slowest transformation rate. However, in a very short time (about $11 \mathrm{~s}$ ), the transformation rate of sample austenized at $1200^{\circ} \mathrm{C}$ became the largest because the growth of bainite sheaves was less likely hindered by austenite grain boundaries, resulting in the largest amount of bainite.

(3) Differing from the commonly accepted viewpoint that the increase in PAGS led to the finer bainite plates in bainitic steels austempered above $\mathrm{M}_{\mathrm{s}}$, the bainite plates became finer firstly and then coarse with PAGS when samples are austempered below Ms.

(4) When the tested low-carbon bainitic steel was austempered below $\mathrm{M}_{\mathrm{s}}$, the 
1

mechanical properties increased initially, followed by a decrease with the increase in PAGS. The best mechanical properties were achieved in the sample austenitized at $1100{ }^{\circ} \mathrm{C}$, whereas the worst properties were found at the highest austenitizing temperature.

\section{Acknowledgements}

The authors gratefully acknowledge the financial supports from the National Nature Science Foundation of China (Nos.51704217, 51874216), the Major Projects of Technological Innovation in Hubei (No.2017AAA116), Hebei Joint Research Fund for Iron and Steel (E2018318013) and the State Scholarship Fund of China Scholarship Council.

\section{$\underline{\text { References }}$}

1. Bag A, Ray KK, Dwarakadasa ES. Influence of martensite content and morphology on tensile and impact properties of high-martensite dual-phase steels. Metall Mater Trans A. 1999; 30: 1193-1202.

2. Kumar A, Singh SB, Ray KK. Influence of bainite/martensite-content on the tensile properties of low carbon dual-phase steels, Mater Sci Eng A. 2008; 474: 270-282.

3. Tian JY, Xu G, Jiang ZY, Hu HJ, et al. Effect of Ni addition on bainite transformation and properties in a 2000 MPa grade ultrahigh strength bainitic steel. Met Mater Int. 2018; 24:1202-1212.

4. Sun SH, Zhao AM, Ding R, et al. Effect of heat treatment on microstructure and mechanical properties of quenching and partitioning steel, Acta Metall Sin (Eng Lett). 2018; 31: 216-224. 
5. Caballero FG, Bhadeshia HKDH, Mawella KJA, et al. Very strong low temperature bainite. Mater Sci Technol. 2002; 18: 279-284.

6. García-Mateo C, Caballero FG, Bhadeshia HKDH. Acceleration of lowtemperature bainite. ISIJ Int. 2003; 43: 285-288.

7. Zhao JW, Jiang ZY. Thermomechanical processing of advanced high strength steels. Prog Mater Sci. 2018; 94: 174-242.

8. Sun J, Jiang T, Wang Y, et al. Effect of grain refinement on high-carbon martensite transformation and its mechanical properties. Mater Sci Eng A 2018; 726: 342-349.

9. Prawoto Y, Jasmawati N, Sumeru K. Effect of prior austenite grain size on the morphology and mechanical properties of martensite in medium carbon steel. J. Mater Sci Technol. 2012, 28: 461-466.

10. Dong J, Liu CX, Liu YC, et al. Influence of austenite grain size on martensite start temperature of Nb-V-Ti microalloyed ultra-high strength steel. Mater. Sci Forum. 2016; 848: 624-632.

11. Hanamura T, Torizuka S, Tamura S, Enokida S, et al. Effect of austenite grain size on the mechanical properties in air-cooled 0.1C-5Mn martensitic steel. Mater Sci Forum. 2014; 783-786: 1027-1032.

12. Yang HS, Bhadeshia HKDH. Austenite grain size and the martensite-start temperature. Scripta Mater. 2009; 60: 493-495.

13. Garcia-Junceda A, Capdevila C, Caballero FG, et al. Dependence of martensite start temperature on fine austenite grain size, Scripta Mater. 2008; 58: 134-137.

14. Lee SJ, Tyne CJV. A kinetics model for martensite transformation in plain carbon 
and low-alloyed steels. Metall Mater Trans A. 2012; 43: 422-427.

15. Brofman PJ, Ansell GS. On the effect of fine grain size on the Ms temperature in Fe-27Ni-0.025C alloys. Metall Mater Trans A. 1983; 14: 1929-1931.

16. Lan LY, Qiu CL, Zhao DW, et al. Effect of austenite grain size on isothermal bainite transformation in low carbon microalloyed steel. Mater Sci Technol. 2011; 27: 1657-1663.

17. Hu F, Hodgson PD, Wu KM. Acceleration of the super bainite transformation through a coarse austenite grain size. Mater Lett. 2014; 122: 240-243. 

Mater. 2016; 112: 96-100.

24. Tian JY, Xu G, Jiang ZY, et al. Transformation behavior and properties of carbidefree bainite steels with different Si contents, 2018; DOI: 10.1002/srin.201800474.

25. Long XY, Zhang FC, Kang J, et al. Low-temperature bainite in low-carbon steel. Mater Sci Eng A. 2014; 594: 344-351.

26. Tian JY, Xu G, Zhou MX, et al. The Effects of $\mathrm{Cr}$ and $\mathrm{Al}$ addition on transformation and properties in low-carbon bainitic steels, Metals. 2017; 7: 40-50.

27. Caballero FG, Bhadeshia HKDH. Very strong bainite. Curr Opin Solid State Mater Sci. 2004; 8: 251-257.

28. Andrews KW, Empirical formulae for the calculation of some transformation temperatures. ISIJ Int. 1965; 203: 721-727.

29. Bhadeshia HKDH. Bainite in Steels. Institute of Materials, London, 1992, 1-450.

30. Yang HS, Bhadeshia HKDH. Uncertainties in dilatometric determination of martensite start temperature. Mater Sci Technol. 2007; 23: 556-560.

31. Da Silva EP, De Knijf D, Xu W, et al. Isothermal transformations in advanced high strength steels below martensite start temperature. Mater Sci Technol. 2015; 31: 808-816.

32. Navarro-López A, Hidalgo J, Sietsma J, et al. Characterization of bainitic/martensitic structures formed in isothermal treatments below the $\mathrm{Ms}_{\mathrm{s}}$ temperature. Mater Charact. 2017; 128: 248-256.

33. Toji Y, Miyamoto G, Raabe D. Carbon partitioning during quenching and 
partitioning heat treatment accompanied by carbide precipitation. Acta Mater. 2015; 86: 137-147.

34. Tariq F, Baloch RA. One-step quenching and partitioning heat treatment of medium carbon low alloy steel. J Mater Eng Perform. 2014; 23: 1726-1739.

35. García-Junceda A, Capdevila C, Caballero FG, et al. Dependence of martensite start temperature on fine austenite grain size. Scripta Mater. 2008; 58: 134-137.

36. Jiang T, Liu HJ, Sun JJ, et al. Effect of austenite grain size on transformation of nanobainite and its mechanical properties. Mater Sci Eng A. 2016; 666: 207-213.

37. Singh K, Kumar A, Singh A. Effect of prior austenite grain size on the morphology of nano-bainitic steels. Metall Mater Trans A. 2018; 49: 1348-1354.

38. Zhou MX, Xu G, Wang L, et al. Effects of austenitization temperature and compressive stress during bainitic transformation on the stability of retained austenite. T Indian I Metals. 2017; 70: 1447-1453.

39. $\mathrm{Hu} \mathrm{H}, \mathrm{Xu} \mathrm{G}$, Wang $\mathrm{L}$, et al. The effects of $\mathrm{Nb}$ and Mo addition on transformation and properties in low carbon bainitic steels. Mater Des. 2015; 84: 95-99.

40. Du WS, Cao R, Yan YJ, et al. Fracture behavior of 9\% nickel high-strength steel at various temperatures: Part 1. Tensile tests. Mater Sci Eng A. 2008; 486: 611-625.

\section{Tables}

Table 1. The calculated volume fractions of B, AM and RA of different samples

\begin{tabular}{cccc}
\hline $\mathbf{T}\left({ }^{\circ} \mathbf{C}\right)$ & $\mathbf{V}_{\text {AM (\%) }}$ & $\mathbf{V}_{\text {B }} \mathbf{( \% )}$ & $\mathbf{V}_{\mathbf{R A}} \mathbf{( \% )}$ \\
\hline 1000 & $28.8 \pm 0.7$ & $31.3 \pm 0.5$ & $6.6 \pm 0.4$ \\
1100 & $34.3 \pm 0.8$ & $37.1 \pm 0.4$ & $14.5 \pm 0.7$ \\
1200 & $40.9 \pm 0.5$ & $43.8 \pm 0.5$ & $12.8 \pm 0.8$ \\
& \multicolumn{2}{c}{24} &
\end{tabular}




$\begin{array}{llll}1250 & 52.3 \pm 0.4 & 26.7 \pm 0.6 & 6.5 \pm 0.5\end{array}$

$\underline{\text { Table 2. }}$ The tensile test results of different samples

\begin{tabular}{ccccc}
\hline T ( $\left.{ }^{\circ} \mathbf{C}\right)$ & TS (MPa) & YS (MPa) & TE (\%) & PSE (GPa\%) \\
\hline $1000{ }^{\circ} \mathrm{C}$ & $1394 \pm 31$ & $998 \pm 19$ & $11.72 \pm 0.45$ & $16.337 \pm 0.244$ \\
$1100{ }^{\circ} \mathrm{C}$ & $1444 \pm 28$ & $1092 \pm 21$ & $13.51 \pm 0.57$ & $19.508 \pm 0.435$ \\
$1200{ }^{\circ} \mathrm{C}$ & $1408 \pm 34$ & $1004 \pm 28$ & $13.08 \pm 0.64$ & $18.416 \pm 0.574$ \\
$1250{ }^{\circ} \mathrm{C}$ & $1286 \pm 25$ & $874 \pm 18$ & $10.92 \pm 0.46$ & $14.043 \pm 0.693$ \\
\hline \multicolumn{5}{r}{ TS-tensile strength; YS-yield strength; TE—total elongation }
\end{tabular}

3

4 
Figures

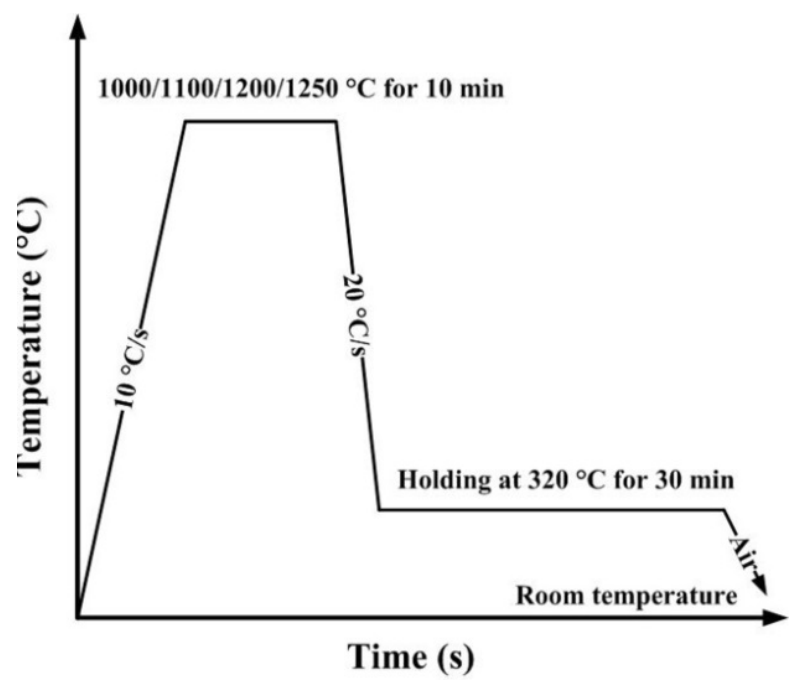

Figure. 1. The experimental procedures 4 

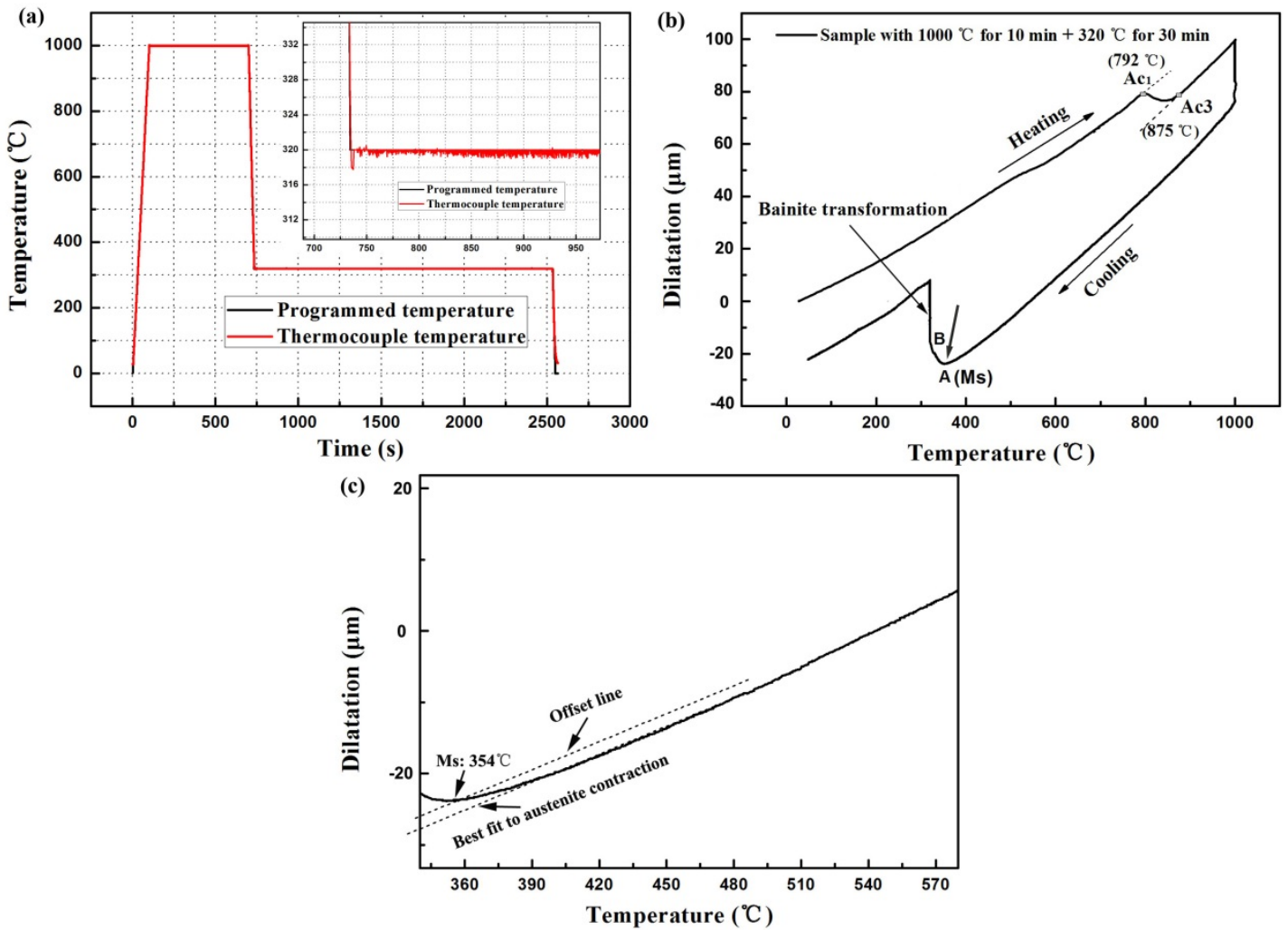

Figure. 2. Examples: (a) the programmed and thermocouple temperature versus time; and (b) dilatation versus temperature during the whole transformation process 4 

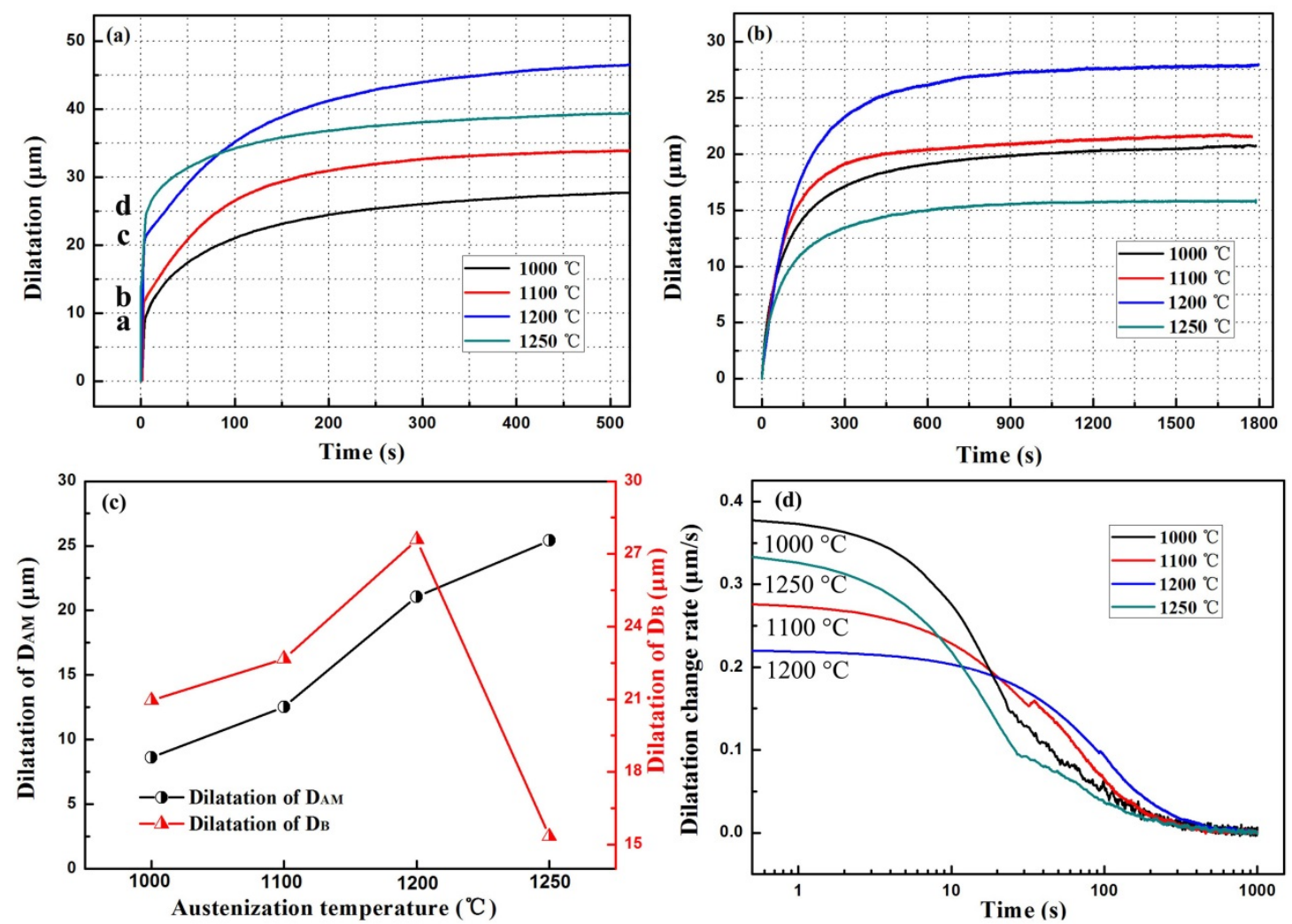

$2 \quad$ Figure. 3 . (a) The curves of the total dilatation versus time; (b) the curves of $D_{B}$

3 versus time; (c) the change trends of $\mathrm{D}_{\mathrm{AM}}$ and $\mathrm{D}_{\mathrm{B}}$ versus austenization temperature; and (d) the curves of dilatation change rate versus time indicating the bainite 

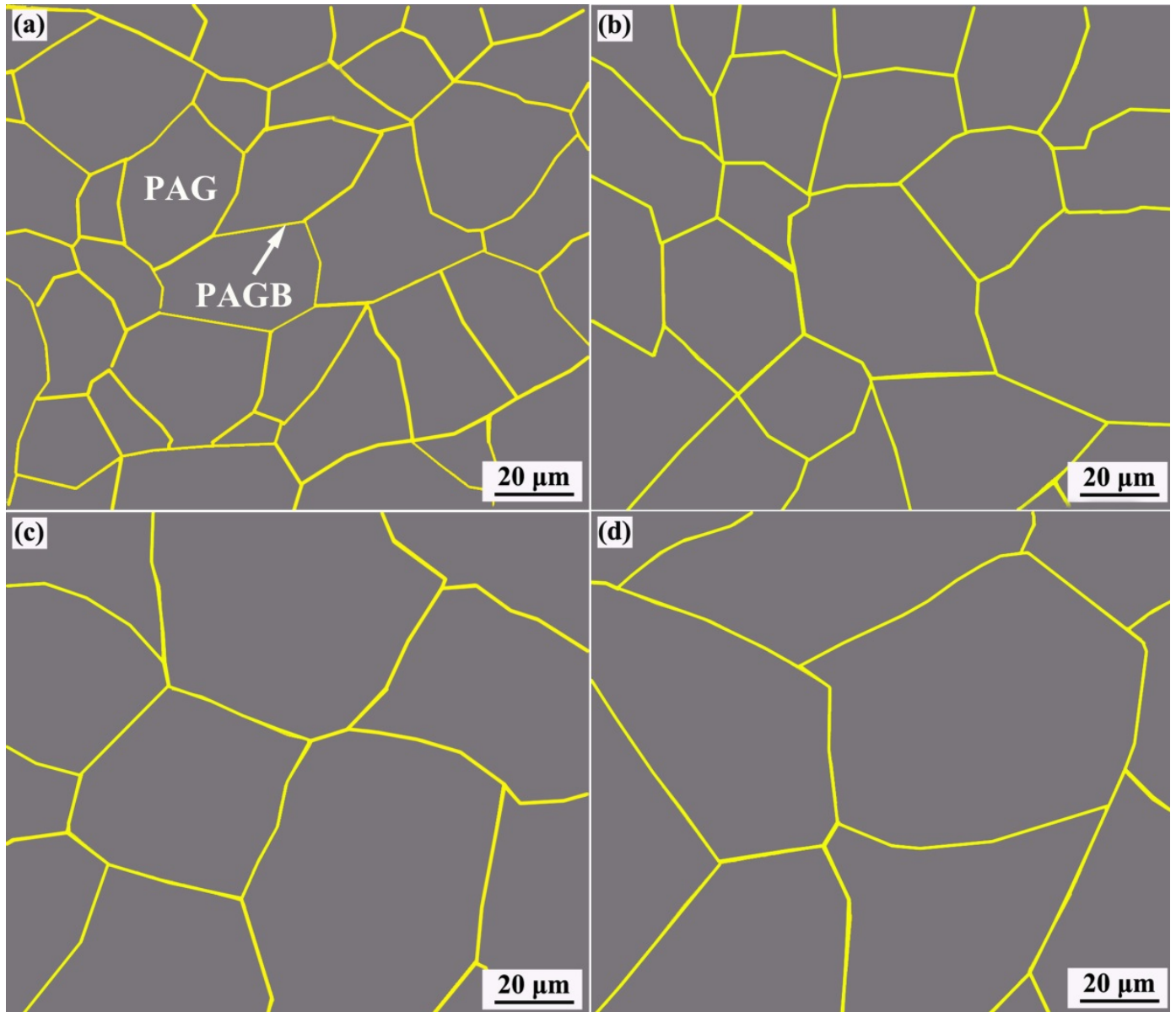

$20 \mu \mathrm{m}$

$2 \quad$ Figure. 4. PAGS for samples austenitized at: (a) $1000^{\circ} \mathrm{C}$; (b) $1100{ }^{\circ} \mathrm{C}$; (c) $1200{ }^{\circ} \mathrm{C}$ 3 and (d) $1250^{\circ} \mathrm{C}$

4 

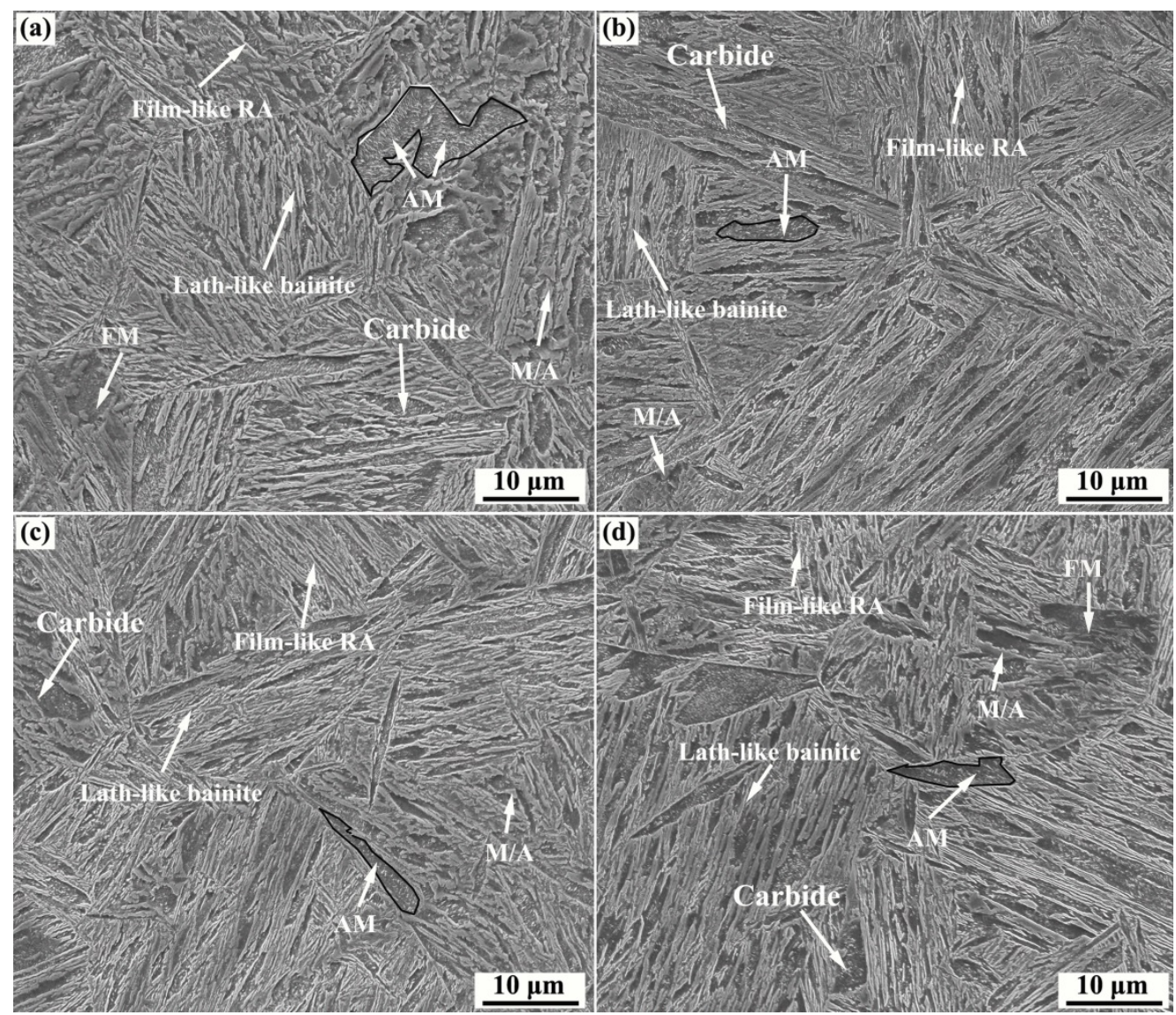

Figure. 5. Typical SEM microstructures after different austenization temperatures:

(a) $1000{ }^{\circ} \mathrm{C}$, (b) $1100{ }^{\circ} \mathrm{C}$, (c) $1200{ }^{\circ} \mathrm{C}$ and (d) $1250{ }^{\circ} \mathrm{C}$ 

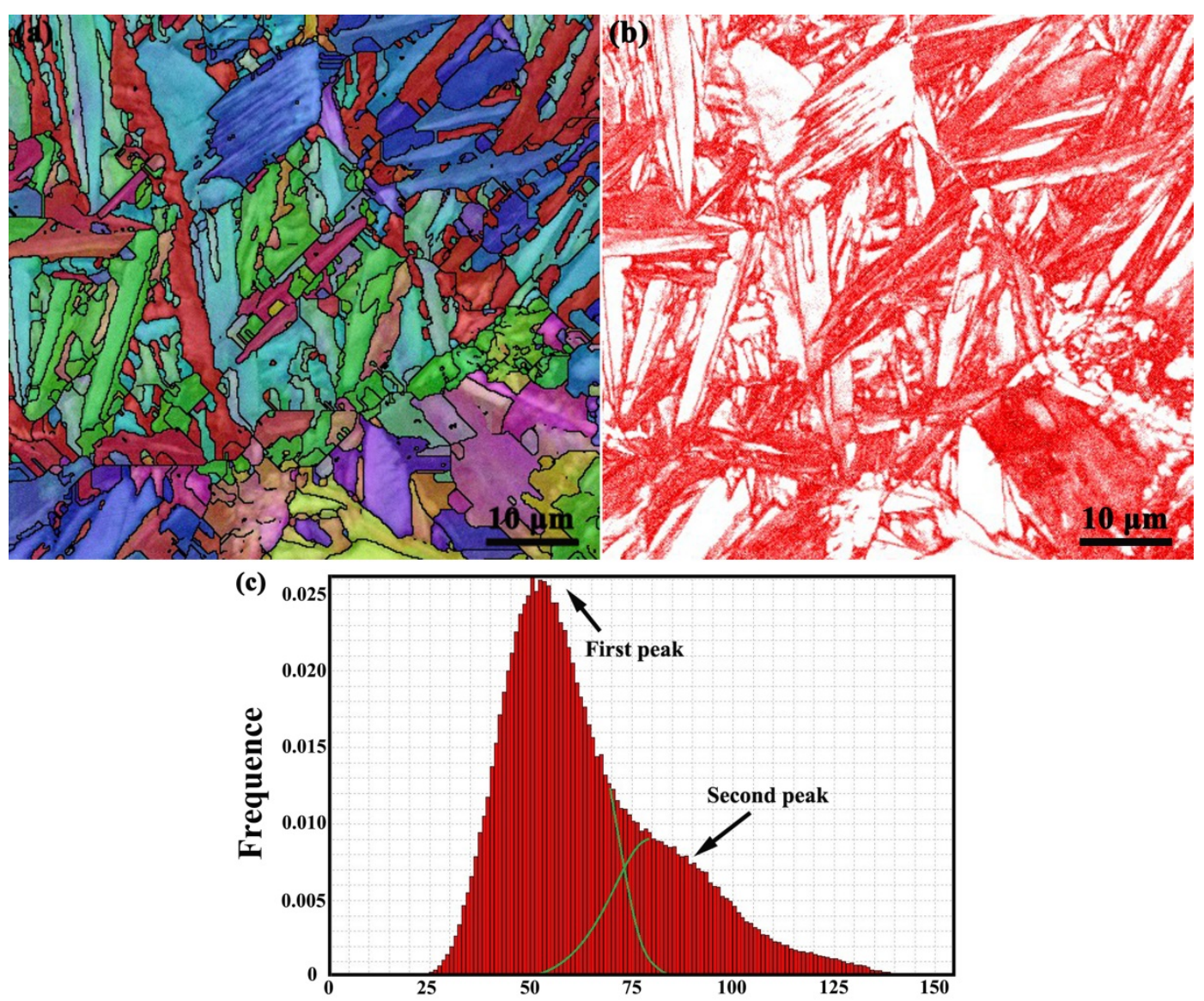

2 Figure. 6. An example of EBSD measurement of sample austenitized at $1250{ }^{\circ} \mathrm{C}$ : (a)

3 crystallographic orientation; (b) the diagram of frequency distribution; and (c) the 


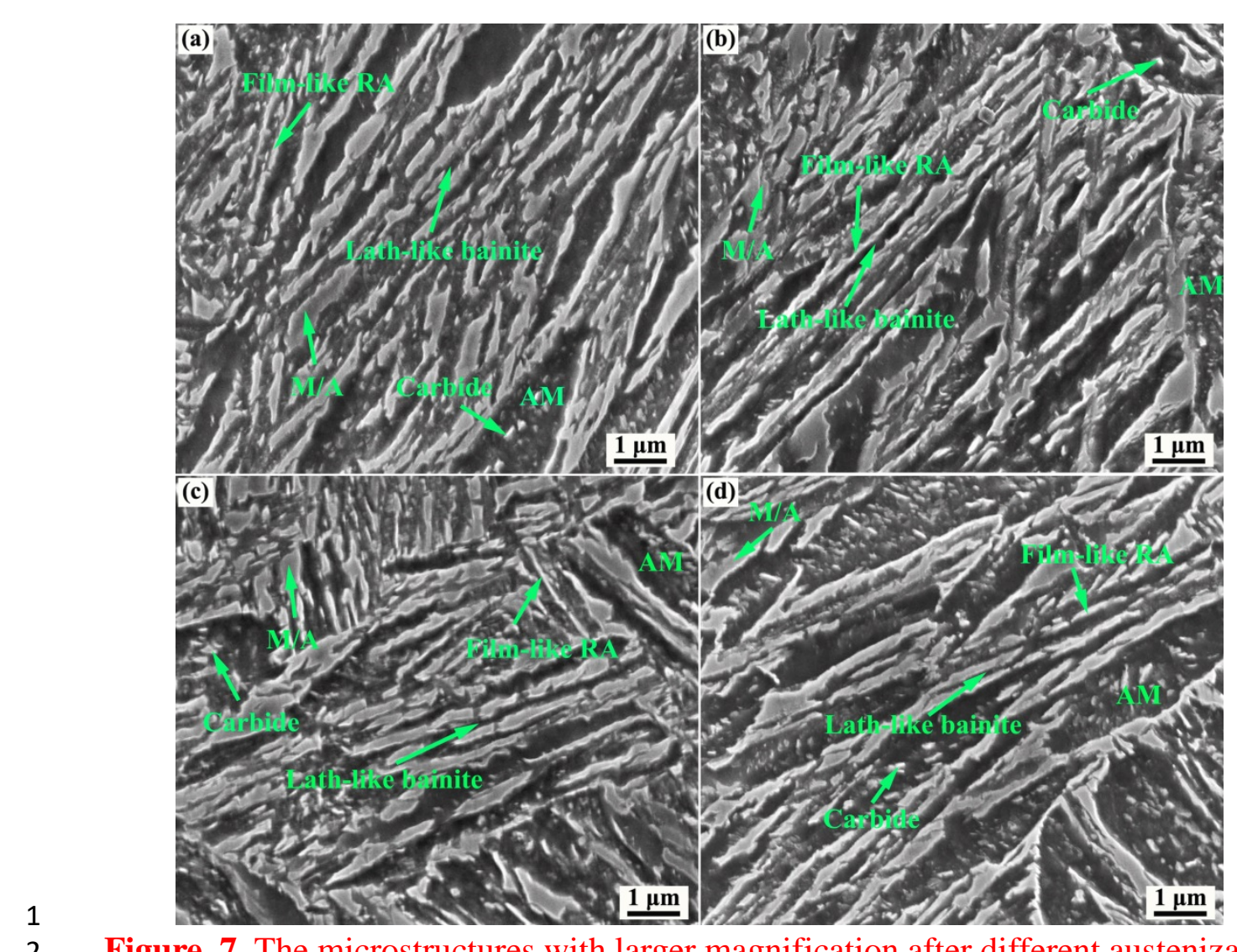

2 Figure. 7. The microstructures with larger magnification after different austenization

temperatures: (a) $1000{ }^{\circ} \mathrm{C}$ and (b) $1100{ }^{\circ} \mathrm{C}$; (c) $1200{ }^{\circ} \mathrm{C}$ and (d) $1250{ }^{\circ} \mathrm{C}$ 


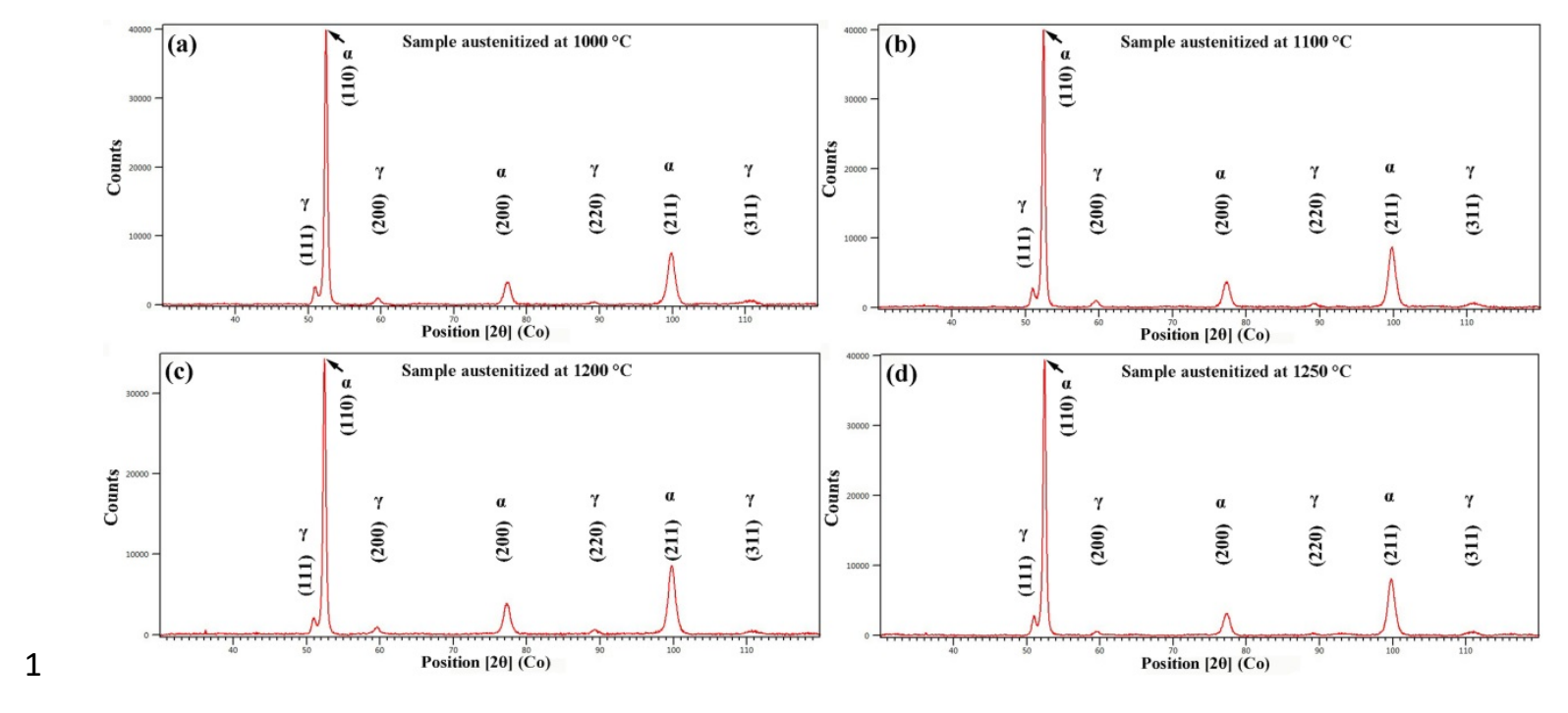

2

Figure. 8. Diffraction patterns of different samples

3 


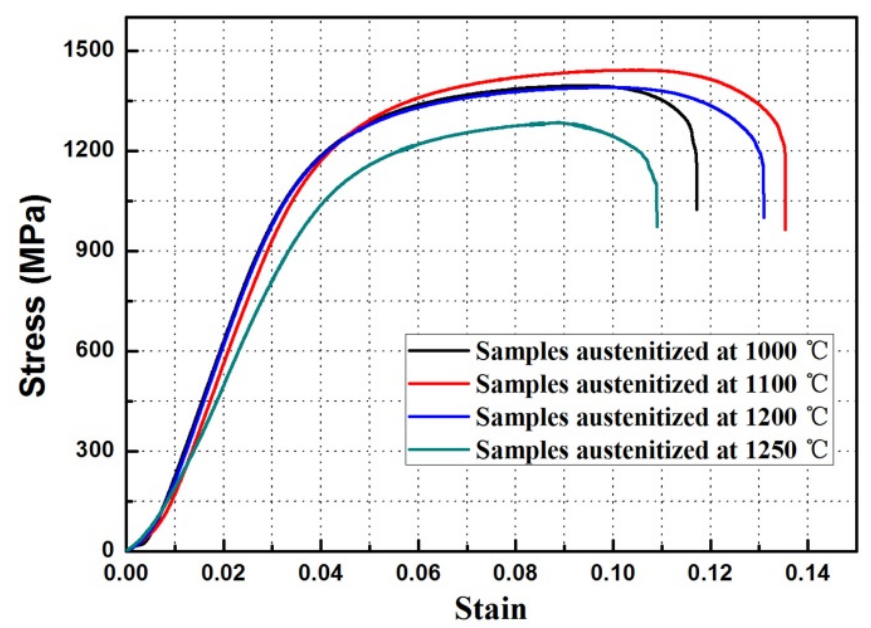

2 Figure. 9. The tensile curves of the samples austenitized at different temperatures 3 


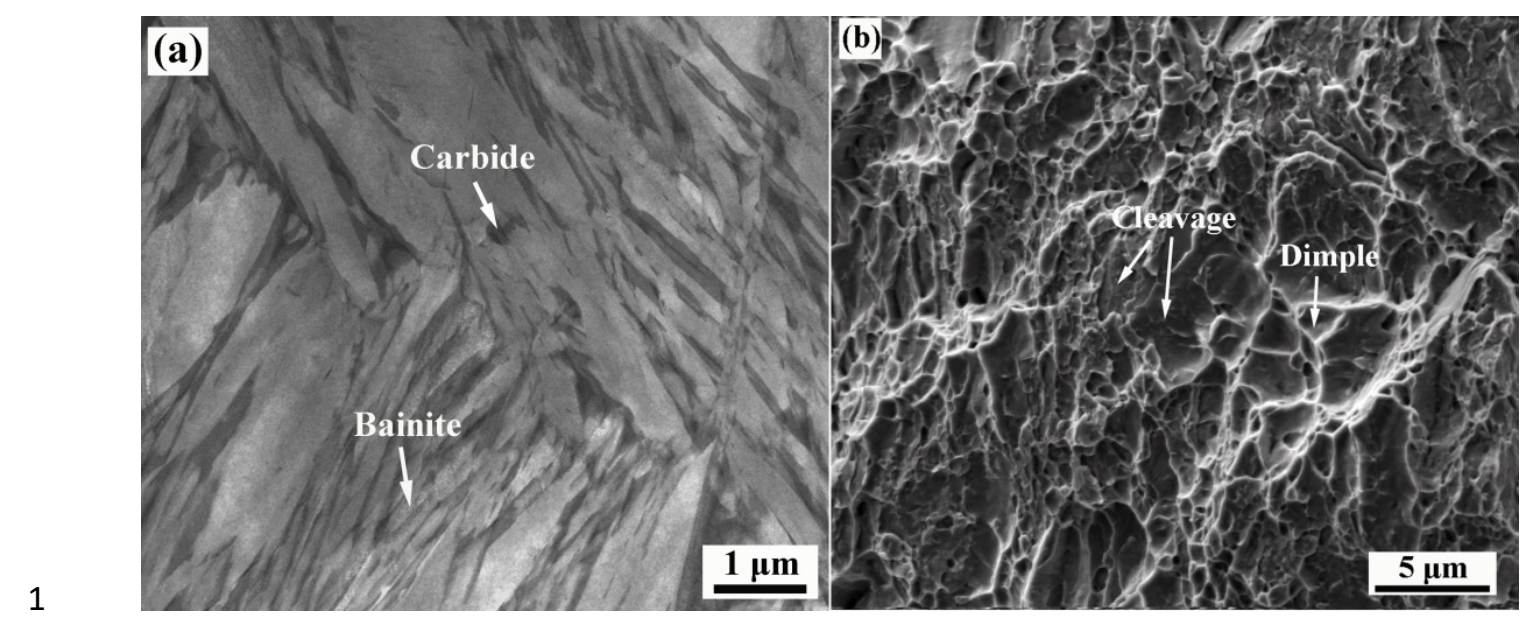

2 Figure. 10. Sample austenitized at $1250^{\circ} \mathrm{C}$ : (a) TEM microstructure and (b) fracture 


\section{Figure captions}

$2 \quad$ Figure. 1. The experimental procedures.

3 Figure. 2. Examples: (a) the programmed and thermocouple temperature versus time;

4 (b) dilatation versus temperature during the whole transformation process and (c) The

5 determination of $\mathrm{Ms}_{\mathrm{s}}$ by the method proposed by Bhadeshia et al. [30].

$6 \quad$ Figure. 3. (a) The curves of the total dilatation versus time; (b) the curves of $D_{\mathrm{B}}$ versus

7 time; (c) the change trends of $\mathrm{D}_{\mathrm{AM}}$ and $\mathrm{D}_{\mathrm{B}}$ versus austenization temperature; and (d) the

8 curves of dilatation change rate versus time indicating the bainite transformation rate

$9 \quad$ Figure. 4. PAGS for samples austenitized at: (a) $1000{ }^{\circ} \mathrm{C}$; (b) $1100{ }^{\circ} \mathrm{C}$; (c) $1200{ }^{\circ} \mathrm{C}$ and 10 (d) $1250^{\circ} \mathrm{C}$.

Figure. 5. Typical SEM microstructures after different austenization temperatures: (a) $1000^{\circ} \mathrm{C}$, (b) $1100^{\circ} \mathrm{C}$, (c) $1200^{\circ} \mathrm{C}$ and (d) $1250^{\circ} \mathrm{C}$.

Figure. 6. An example of EBSD measurement of sample austenitized at $1250{ }^{\circ} \mathrm{C}$ : (a) crystallographic orientation; (b) the diagram of frequency distribution; and (c) the curves of frequency versus band contrast.

Figure. 7. The microstructures with larger magnification after different austenization temperatures: (a) $1000^{\circ} \mathrm{C}$ and (b) $1100{ }^{\circ} \mathrm{C}$; (c) $1200{ }^{\circ} \mathrm{C}$ and (d) $1250{ }^{\circ} \mathrm{C}$.

Figure. 8. Diffraction patterns of different samples.

Figure. 9. The tensile curves of the samples austenitized at different temperatures.

Figure. 10. Sample austenitized at $1250{ }^{\circ} \mathrm{C}$ : (a) TEM microstructure and (b) fracture morphology. 